\title{
Performance of laying hens on diets containing Euroly- sine bacterial protein or Pekilo protein
}

\author{
MATTI NÄSI
}

Department of Animal Husbandry, University of Helsinki, 00710 Helsinki 71

\begin{abstract}
The investigation was made to determine to what extent soybean meal and fish meal protein in the diet of laying hens can be replaced by Eurolysine bacterial protein, a by-product of lysine fermentation, or with Pekilo protein. In a 24-week laying trial the inclusion levels of Eurolysine in the diet were $0-4.0-7.9-11.9 \%$ and those of Pekilo $0-6.3-12.7-18.0 \%$, or $0-33-66-100 \%$ of the protein supplement. Eurolysine contained $68.5 \%$ crude protein $53.5 \%$ true protein and $6.9 \%$ ether extract in DM and the corresponding values of Pekilo were $43.3 \%, 38,8 \%$ and $1.4 \%$. The average laying rates decreased with increasing inclusion of Eurolysine, and replacement of the protein supplement by Pekilo also lowered egg production, but the differences between the treatments were not significant $(P>0.05)$. Feed intakes were increased $(\mathrm{P}<0.05)$ by inclusion of SCP. Feed conversion efficiency did not differ significantly among the treatments $(\mathrm{P}>0.05)$. Mortality increased vith inclusion of both types of SCP in the diets, but the principal cause of death was cannibalism.
\end{abstract}

\section{Introduction}

In recent years there has been a great deal of interest in the development of single cell proteins (SCP) from yeasts, fungi and bacteria grown on various substrates. In many experiments equally good laying results have been achieved when SCP products have replaced conventional protein sources (WALDROUP and HAZEN 1975, VOGT et al. 1975, SHANNON et al. 1976, VOGT et al. 1978, WHITTEMOORE et al. 1978).

In Finland investigations have been made with diets for broilers and layers including protein from the microfungi (Paecilomyces varioti) known as Pekilo and from Torula yeast (Silva) cultivated in sulphite spent liquor from the pulping industry (POUTIAINEN 1973, SALO 1977, KIISKINEN 1979). In these experiments at least half of the protein supplement could be of microbial origin without adverse effect on production or feed conversion.

Eurolysine is a by-product of Bacterium lactofermentum, which is used during the aerobic fermentation of beet molasses for manufacturing L-lysine. The crude protein content is $76 \%$ and the lysine content is also high.

This report concerns the performance of layers in a feeding trial in which soybean and fishmeal protein were gradually replaced by Eurolysine or Pekilo protein. 


\section{Material and Methods}

The feeding experiment was carried out with 504 White Leghorns, strain SK-51 (Siipikarjanhoitajain Liitto). The hens were housed in stair-model cages containing three birds. The temperature, relative humidity, light and ventilation rate jin the henhouse were controlled. The trial started when the hens were 30 weeks old. After a two-week standardization period, when the hens were fed a commercial layers' ration, the birds were distributed at random among seven different treatments, 4 or 5 subgroups of 12-18 hens being allocated to each treatment. During a two-week transition period the hens were gradually changed to the experimental diets. The experimental mashes were prepared by Vaasa Mills Co. and had the form of granules 2.5 $\mathrm{mm}$ in diameter. The ingredients of the experimental feeds are shown in Table 1.

\section{The treatments and codes were as follows}

1. EPO, Fish meal (FM) and soybean meal (SMB), $(50 \%+50 \%)$ protein supplement

2. E33, Eurolysine replacing $33 \%$ of $F M+$ SBM supplement

3. E66, Eurolysine replacing $66 \%$ of FM + SBM supplement

4. E100, Eurolysine replacing $100 \%$ of FM + SBM supplement

5. P33, Pekilo replacing $33 \%$ of FM + SBM supplement

6. P66, Pekilo replacing $66 \%$ of FM + SBM supplement

7. P100, Pekilo replacing $100 \%$ of FM + SBM supplement

Table 1. Composition of the mixtures.

\begin{tabular}{|c|c|c|c|c|c|c|c|}
\hline \multirow{2}{*}{$\begin{array}{l}\text { Ingredients, } \\
\qquad \%\end{array}$} & \multicolumn{7}{|c|}{ Treatments } \\
\hline & 1. EPO & 2. E33 & 3. E66 & 4. E100 & 5. P33 & 6. P66 & 7. $\mathrm{P} 100$ \\
\hline Barley & 55.7 & 56.2 & 56.8 & $\mathbf{5 7 . 2}$ & 53.9 & 52.0 & 50.3 \\
\hline Oats & 20.0 & 20.0 & 20.0 & 20.0 & 20.0 & 20.0 & 20.0 \\
\hline Fish meal & 6.8 & 4.4 & 2.0 & - & 4.4 & 2.0 & - \\
\hline Soybean meal & 6.8 & 4.4 & 2.0 & - & 4.4 & 2.0 & - \\
\hline Eurolysine & - & 4.0 & 7.9 & 11.1 & - & - & - \\
\hline Pekilo & - & - & - & - & 6.3 & 12.7 & 18.0 \\
\hline Rapeseed oil & 2.0 & 2.0 & 2.0 & 2.0 & 2.0 & 2.0 & 2.0 \\
\hline $\mathrm{CaCO}_{3}$ & 6.6 & 6.7 & 6.8 & 7.0 & 6.7 & 6.8 & 7.0 \\
\hline $\mathrm{CaHPO}_{4} \cdot 2 \mathrm{H}_{2} \mathrm{O}$ & 1.5 & 1.7 & 1.9 & 2.1 & 1.7 & 1.9 & 2.1 \\
\hline \multicolumn{8}{|l|}{ Trace elements } \\
\hline $\operatorname{mix}^{1}$ & 0.5 & 0.5 & 0.5 & 0.5 & 0.5 & 0.5 & 0.5 \\
\hline \multicolumn{8}{|l|}{ Vitamin supple- } \\
\hline ment $^{2}$ & 0.115 & 0.115 & 0.115 & 0.115 & 0.115 & 0.115 & 0.115 \\
\hline
\end{tabular}

1 Provided per kg feed: magnesium $130 \mathrm{mg}$, sodium $992 \mathrm{mg}$, iron $30 \mathrm{mg}$, chloride $900 \mathrm{mg}$, zinc $60 \mathrm{mg}$, iodine $0.70 \mathrm{mg}$, copper $3.5 \mathrm{mg}$, manganese $79 \mathrm{mg}$, cobolt $0.798 \mathrm{mg}$, molybdenum $0.020 \mathrm{mg}$ and selenium $0.066 \mathrm{mg}$.

${ }^{2}$ Provided per kg feed: vitamin A $24000 \mathrm{IU}$, vitamin D $2000 \mathrm{IU}$, vitamin E $18.20 \mathrm{mg}$, vitamin $\mathrm{K}_{3} 2.22 \mathrm{mg}$, vitamin $B_{2} 4.8 \mathrm{mg}, B_{6} 3.42 \mathrm{mg}, B_{12} 0.01 \mathrm{mg}$, biotin $0.02 \mathrm{mg}$, niacin $20 \mathrm{mg}$, folic acid $0.58 \mathrm{mg}$, pantothenic acid $9.39 \mathrm{mg}$, choline $100 \mathrm{mg}$, carophyllred $0.65 \mathrm{mg}$. 
The period during which the treatments were compared lasted 24 weeks, from week 34 to week 58 in the life of the hens. The diets were fed ad libitum and the feed consumption was recorded for each subgroup for a 28-day period. Egg production was recorded daily by weighing and counting the eggs. The feed ingredients and experimental mixtures were analysed according to the standard methods. The mineral contents of the feeds were analysed with an atomic absorption spectrophotometer (Varian Techron AA 1000) and phosphorus by the method of TAUSSKY and SHORR (1953). The amino acid contents of Eurolysine and Pekilo were determined with a gas chromatograph, Hewlett Packard $5710 \mathrm{~A}$, as described by NÄSI and HUIDA (1982). Pepsin-HC1-soluble protein was determined after 20-h digestion of a $0.5 \mathrm{~g}$ sample in $50 \mathrm{ml} 0.1 \mathrm{~N} \mathrm{HC1}$ containing $50 \mathrm{mg}$ pepsin. The HYLPS programme (ANON. 1981) was used for calculating the production results and for the statistical analysis.

\section{Results and Discussion}

The chemical composition of the feed ingredients and the experimental mixtures is presented in Tables 2 and 4. The crude protein (CP) content of Eurolysine, $68.5 \%$, was lower than that given by the manufacturer, $76 \%$ of DM. The protein content of Pekilo, $43.4 \%$, was also lower than the values reported earlier. This caused a lower protein content in the diets containing single cell protein than in the others. The crude protein content of the treatments varied from 16.1 to $17.9 \%$ of DM. However, the metabolizable energy (ME) content of the mixtures containing SCP was also lower because of inclusion of larger calcium and phosphorus supplements, and thus the CP: ME ratios were almost the same, $12.8-13.9 \mathrm{~g} \mathrm{CP} / \mathrm{MJ} \mathrm{ME}$.

The ME content of Eurolysine has been reported to be $8.4 \mathrm{MJ} / \mathrm{kg}$ for poultry (LARBIER 1979). When Eurolysine was used as protein in a digestibility trial with pigs the ME value obtained was $11.1 \mathrm{MJ} / \mathrm{kg}$ DM (NÄSI 1982). The present digestibilities for organic matter and crude protein were $55.0 \%$ and $64.3 \%$, respectively. The pepsin- $\mathrm{HCl}$-soluble protein in Eurolysine constituted only $52.9 \%$ of crude protein, which is rather low compared with

Table 2. Chemical composition of the ingredients of the mixtures ( $\%$ of DM).

\begin{tabular}{lrrrrrr}
\hline $\begin{array}{l}\text { Composition } \\
\%\end{array}$ & Barley & Oats & Fish meal & $\begin{array}{c}\text { Soybean } \\
\text { meal }\end{array}$ & Eurolysine & Pekilo \\
\hline Dry matter \% & 87.6 & 87.5 & 91.4 & 87.7 & 92.6 & 94.1 \\
Ash & 3.0 & 3.0 & 14.2 & 6.4 & 4.3 & 5.4 \\
Crude protein & 10.9 & 13.6 & 72.3 & 49.2 & 68.5 & 43.3 \\
True protein & 10.2 & 12.5 & 57.9 & 47.4 & 53.5 & 38.8 \\
Ether extract & 2.4 & 5.6 & 9.0 & 2.2 & 6.9 & 1.4 \\
Crude fibre & 6.8 & 8.4 & 0.3 & 7.5 & 0.6 & 7.7 \\
N-free extract & 76.9 & 69.4 & 4.2 & 34.7 & 19.7 & 42.2 \\
\hline
\end{tabular}


Table 3. Comparison of the amino acid composition of Eurolysine and Pekilo protein.

\begin{tabular}{lcc}
\hline Amino acids $\mathrm{g} / 16 \mathrm{~g} \mathrm{~N}$ & Eurolysine & Pekilo \\
\hline Alanine & 7.0 & 5.6 \\
Arginine & 3.4 & 4.6 \\
Aspartic acid & 7.1 & 7.1 \\
Glutamic acid & 9.7 & 11.5 \\
Glycine & 3.7 & 4.2 \\
Histidine & 0.9 & 1.2 \\
Isoleucine & 3.6 & 3.5 \\
Leucine & 5.8 & 6.1 \\
Lysine & 8.3 & 5.5 \\
Methionine & 0.6 & 0.5 \\
Phenylalanine & 3.0 & 3.3 \\
Proline & 2.6 & 3.5 \\
Serine & 3.0 & 3.7 \\
Threonine & 3.7 & 3.7 \\
Tyrosine & 2.1 & 2.7 \\
Valine & 4.5 & 4.3 \\
\hline
\end{tabular}

Table 4. Chemical composition (\% of DM) and feed values of the mixtures.

\begin{tabular}{|c|c|c|c|c|c|c|c|}
\hline & \multicolumn{7}{|c|}{ Treatments } \\
\hline & 1. EPO & 2. E33 & 3. E66 & 4. E100 & 5. P33 & 6. P66 & 7. P100 \\
\hline \multicolumn{8}{|l|}{ Chemical composition } \\
\hline Dry matter $\%$ & 88.4 & 88.1 & 88.4 & 88.2 & 88.9 & 88.9 & 88.6 \\
\hline Ash & 9.8 & 9.9 & 10.2 & 10.0 & 10.0 & 9.8 & 9.4 \\
\hline Crude protein & 17.9 & 17.1 & 16.9 & 16.1 & 17.6 & 16.8 & 16.2 \\
\hline True protein & 16.1 & 15.1 & 14.8 & 13.6 & 15.7 & 15.0 & 14.6 \\
\hline Ether extract & 5.5 & 5.6 & 5.5 & 5.4 & 5.1 & 5.2 & 5.0 \\
\hline Crude fibre & 8.1 & 6.6 & 6.7 & 6.5 & 6.5 & 6.7 & 7.7 \\
\hline NFE & 58.7 & 60.8 & 60.7 & 62.0 & 60.8 & 61.5 & 61.7 \\
\hline Phosphorus g/kg & 7.03 & 7.51 & 7.61 & 7.84 & 7.34 & 7.78 & 7.80 \\
\hline Calcium $\mathrm{g} / \mathrm{kg}$ & 21.08 & 23.38 & 25.38 & 25.34 & 24.62 & 24.24 & 23.35 \\
\hline Magnesium $\mathrm{g} / \mathrm{kg}$ & 2.03 & 1.86 & 1.82 & 1.68 & 1.83 & 1.95 & 1.90 \\
\hline Potassium g/kg & 5.84 & 5.57 & 4.88 & 4.56 & 4.91 & 4.40 & 4.40 \\
\hline Sodium $\mathrm{g} / \mathrm{kg}$ & 0.25 & 0.20 & 0.19 & 0.18 & 0.18 & 0.18 & 0.15 \\
\hline Iron $\mathrm{mg} / \mathrm{kg}$ & 267 & 248 & 325 & 241 & 234 & 233 & 226 \\
\hline Copper mg/kg & 15 & 15 & 15 & 15 & 13 & 15 & 17 \\
\hline Zinc $\mathrm{mg} / \mathrm{kg}$ & 180 & 162 & 183 & 184 & 183 & 198 & 206 \\
\hline Manganese $\mathrm{mg} / \mathrm{kg}$ & 135 & 124 & 141 & 141 & 149 & 163 & 161 \\
\hline \multicolumn{8}{|l|}{ Feed values } \\
\hline ME MJ/kg feed & 11.43 & 11.20 & 10.97 & 10.77 & 11.37 & 11.29 & 11.22 \\
\hline Crude protein $\%$ & 15.9 & 15.1 & 14.9 & 14.2 & 15.6 & 14.9 & 14.4 \\
\hline
\end{tabular}

$93.4 \%$ for soybean meal, $88.7 \%$ for fish meal and $71.0 \%$ for Pekilo protein. The low values for protein digestibility suggest careless treatment during preparation presumably in drying.

In bacterial protein the nucleic acid nitrogen constitutes $15-27 \%$ of total 
nitrogen and in yeast $13-27 \%$ (SCHULZ and PETERSEN 1979). LEHTOMÄKI (1979) reports that the nucleic acid content in Pekilo is $9.6-10.8 \%$ when the crude protein content is $\mathbf{5 1 - 6 3 \%} \%$. Absorption of nucleic acids is fairly effective, 66-87\% (SHANNON and McNAB 1973, GREIFE et al. 1981), but they are of minor value as a protein source for monogastric animals (ROTH and KIRCHGESSNER 1980).

The amino acid composition of Eurolysine and Pekilo is shown in Table 3. The lysine content is high $8.3 \mathrm{~g} / 16 \mathrm{~g} \mathrm{~N}$, exceeding the value for fish meal. Like other microbial products Eurolysine is poor in sulphur-containing amino acids (SCHULZ and OSLAGE 1976). Gas chromatography gave a methionine content of only $0.6 \mathrm{~g} / 16 \mathrm{~g} \mathrm{~N}$. The manufacturer gives a value of $1.37 \mathrm{~g}$. Methionine is the primary limiting amino acid in poultry diets and improved performance has been achieved by LD-methionine supplementation in microbial protein feeding (WALDROUP and HAZEN 1975, SCHULZ and OSLAGE 1976, WHITTEMORE et al. 1978, KIISKINEN 1979). In diets for pigs the digestibilities of most amino acids were lower with Eurolysine as protein supplement than with soybean meal (NÄSI and HUIDA 1982).

The production results with the different treatments are shown in Table 4. During the standardization period, when the hens were aged 31 weeks, the laying rate averaged $88 \%$.

During the experimental period of 24 weeks the average laying rates fell and the trends of each treatment are shown in Figure 1. As soybean meal and fish meal were replaced by Eurolysine, the laying rates gradually decreased, the difference between groups EPO and E100 being $6.1 \%$. Replacement with Pekilo also gave lower laying rates at the levels of 33 and $100 \%$, but at $66 \%$ replacement the laying rate was $0.9 \%$-units higher than that of the control. The differences between the treatments were not statistically significant $(P>0.05)$. The average egg weight also decreased gradually with inclusion of single cell protein in the diets, but not significantly $(P>0.05)$.

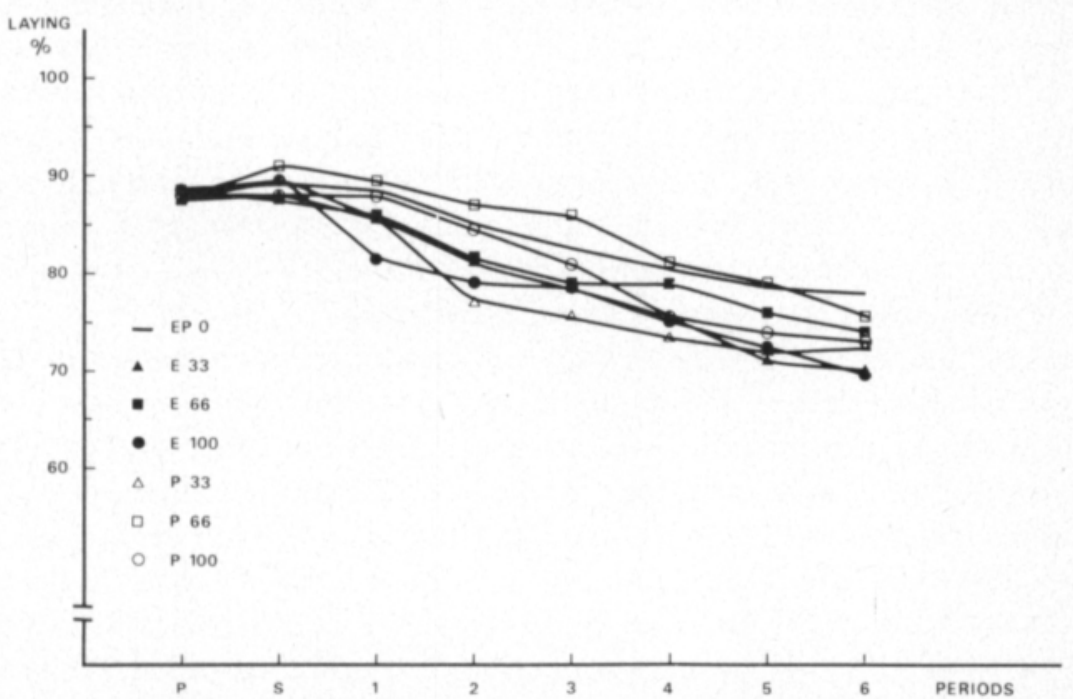

Figure 1. Average laying rates for the treatments during the standarization period and the 24-week test period. 
Table 5. Production results from experiment with Eurolysine and Pekilo as protein supplement for laying hens.

Treatments

\begin{tabular}{lllllll}
\hline 1. $\mathrm{EPO}$ & 2. E33 & 3. E66 & 4. E100 & 5. P33 & 6. P66 & 7. P100
\end{tabular}

\begin{tabular}{|c|c|c|c|c|c|c|c|}
\hline \multicolumn{8}{|l|}{ Number of hens } \\
\hline Beginning of expt. & 75 & 76 & 79 & 76 & 59 & 62 & 59 \\
\hline End of expt. & 73 & 72 & 72 & 68 & 52 & 59 & 49 \\
\hline Mortality \% & 2.7 & 5.3 & 8.9 & 10.5 & 11.9 & 4.8 & 16.9 \\
\hline \multicolumn{8}{|l|}{ Laying } \\
\hline \multicolumn{8}{|l|}{ Laying rate, initial } \\
\hline \multicolumn{8}{|l|}{ Laying rate, test } \\
\hline period (168d) & $82.1^{2}$ & $77.0^{a}$ & $79.2^{2}$ & $76.0^{a}$ & $76.0^{2}$ & $83.0^{4}$ & $79.4^{2}$ \\
\hline Eggs g/hen/d & $49.2^{2}$ & $45.5^{\mathrm{a}}$ & $46.4^{2}$ & $43.8^{\mathrm{a}}$ & $45.0^{2}$ & $49.1^{2}$ & $46.7^{a}$ \\
\hline Egg weight, g & $60.0^{2}$ & $59.3^{2}$ & $58.7^{a}$ & $57.7^{a}$ & $59.2^{2}$ & $59.3^{a}$ & $58.9^{4}$ \\
\hline \multicolumn{8}{|l|}{ Feed intake } \\
\hline Feed g/hen/d & $126^{b}$ & $125^{\text {be }}$ & $128^{a b}$ & $134^{\text {ad }}$ & $130^{a b}$ & $128^{a b}$ & $133^{a}$ \\
\hline Feed DM g/hen/d & $111^{\mathrm{b}}$ & $110^{\text {be }}$ & $111^{b}$ & $118^{\text {ad }}$ & $115^{\mathrm{ab}}$ & $114^{\mathrm{ab}}$ & $118^{\text {ad }}$ \\
\hline Feed CP g/hen/d & $19.9^{\mathrm{ab}}$ & $18.8^{\text {be }}$ & $18.8^{\text {ae }}$ & $19.0^{\mathrm{ab}}$ & $20.2^{\text {ad }}$ & $19.1^{\mathrm{ab}}$ & $19.1^{\mathrm{ab}}$ \\
\hline Feed ME MJ/hen/d & $1.43^{\mathrm{ab}}$ & $1.40^{\mathrm{b}}$ & $1.38^{\text {be }}$ & $1.44^{\text {ad }}$ & $1.47^{a}$ & $1.45^{\mathrm{ab}}$ & $1.49^{\text {ad }}$ \\
\hline \multicolumn{8}{|c|}{ Feed conversion efficiency } \\
\hline Feed kg/kg eggs & $2.56^{\mathrm{a}}$ & $2.76^{2}$ & $2.72^{2}$ & $3.07^{2}$ & $2.97^{a}$ & $2.62^{2}$ & $2.88^{\mathrm{a}}$ \\
\hline Feed DM kg/kg eggs & $2.26^{2}$ & $2.43^{a}$ & $2.40^{2}$ & $2.71^{2}$ & $2.62^{2}$ & $2.32^{2}$ & $2.55^{a}$ \\
\hline Feed $\mathrm{CP}$ g/kg eggs & $406^{2}$ & $416^{2}$ & $406^{2}$ & $436^{2}$ & $451^{2}$ & $389^{2}$ & $412^{2}$ \\
\hline Feed ME MJ $/ \mathrm{kg}$ eggs & $29.2^{2}$ & $30.9^{2}$ & $29.8^{\mathrm{a}}$ & $33.1^{2}$ & $33.6^{2}$ & $29.5^{\mathrm{a}}$ & $32.2^{\mathrm{a}}$ \\
\hline
\end{tabular}

Differences between means with different letters were statistically significant. $(\mathrm{a}, \mathrm{b},(\mathrm{P}<0.05), \mathrm{d}, \mathrm{e}, \mathrm{P}<0.01)$

The feed intakes increased when the diets were supplemented with Eurolysine of Pekilo $(\mathrm{P}<0.05,0.01)$. The ME values of those diets were lower than the value of the control diet due to higher mineral supplementation. The crude protein and ME intakes differed significantly between treatments $(\mathrm{P}<0.05,0.01)$. The feed conversion deteriorated as an increasing percentage of conventional protein supplement was replaced by Eurolysine or Pekilo. The conversion ratios of crude protein and $\mathrm{ME}$ also deteriorated slightly, though the differences were not statistically significant $(P>0.05)$.

Mortality increased gradully with increasing supplementation with Eurolysine or Pekilo, but in almost every case the cause of death was cannibalism. Post-mortem and histological examinations made on hens from every group did not reveal any abnormality due to SCP feeding.

Single cell protein has been used successfully in poultry feeding, and the maximum level of safe replacement has been $50 \%$ of dietary protein (POUTIAINEN 1973, SHANNON et al. 1975, VOGT et al. 1975, 1978, SALO 1977, KIISKINEN 1979). When the proportion of the SCP protein has been 50 $\%$ or more, production and feed utilization in layers has usually deteriorated. In this experiment the diets supplemented with SCP gave a poorer perform- 
ance than the the control diet containing $6.8 \%$ fish meal. The diets containing Eurolysine of Pekilo were not supplemented with methionine. The digestibility of methionine was also rather low in the pig digestibility trial (NÄSI and HUIDA 1982). The reason for the lower egg production could be the deficiency of sulphur-containing amino acids.

Eurolysine bacterial protein has been used as a protein supplement for broilers and $5 \%$ Eurolysine inclusion did not affect weight gain or feed conversion. Higher inclusion rates, $10 \%$ or $15 \%$, reduced weight gains (van WEERDEN and SCHUTTE 1977).

The results of this study suggest that Eurolysine bacterial protein and Pekilo protein can be used as protein sources for laying hens, and can compose up to $50 \%$ of the protein supplement in the diet, provided account is taken of the requirements for sulphur-containing amino acids.

Acknowledgements. The author is indebted to Mr. Jukka Haikonen and Mr. Mikko Ranta for technical assistance and to Berner Co. for financial support.

\section{References}

ANON. 1981. HYLPS-käsikirja. Helsingin yliopiston laskentakeskus. Mimeograph.

GREIFE, H. A., MOLNAR, S. \& GÜNTHER, K.-D. 1981. Weitere Untersuchungen zur N-Verwertung des $\mathrm{H}_{2}$-oxidierenden Bacterienstammes Alcanigenes entrophus und alimentärer Ribonukleinesäure durch wachsende Broiler. Arch. Geflügelk. 45: 57-68.

LARBIER, M. 1979. Alimentary value of the protein concentrate C.S.C. determined with the fattening pullets. Poult. Res. Cent. I.N.R.A. 12 p. Mimeogr.

LEHTOMÄKI, M. 1979. The variation of the chemical composition of Pekilo product. Pekilo-symp. Tampere 1978. Inst. Anim. Husb. Rep. No 12: 21-23.

KIISKINEN, T. 1979. Yksisoluvalkuainen siipikarjan rehuna. Koe kotimaisilla pekilo- ja silvaproteiineilla. Suipikarja 1979 (4): 97-100.

NÄSI, M. 1982. Nutritive value of Eurolysine bacterial protein and Pekilo protein for growing pigs. J. Scient. Agric. Soc. Finl. 54: 263-269.

— , HUIDA, L. 1982. Digestibility of amino acids in pig diets containing Eurolysine bacterial protein or Pekilo protein with special reference to a gas chromatographic method used in amino acid determination. J. Scient. Agric. Soc. Finl. 54: 279-285.

POUTIAINEN, E. 1973. Pekilo-proteiini munivien kanojen ja broilereiden ruokinnassa. Siipikarja 1973: 247-255.

ROTH, F. X. \& KIRCHGESSNER, M. 1980. Alimentär zugeführte Nukleinsäuren in N-Stoffwechsel von Monogastriden. Arch. Tierernähr. 30: 77-88.

SALO, M-L. 1977. Silvaproteiini munivien kanojen valkuaisrehuna. Siipikarja 1977 (61): 151-155.

SCHULZ, E. \& OSLAGE, H. J. 1976. Composition and nutritive value of single-cell protein (SCP). Anim. Feed. Sci. Technol. 1: 9-24.

SCHULZ, E. \& PETERSEN, U. 1979. Value of SCP for animal nutrition. Proc. COST-workshop on Production and Feeding of SCP. JULICH p. 79-112.

SHANNON, D. W. F., McNAB, J. M. 1973. The digestibility of the nitrogen, amino acids, lipid, carbohydrates, ribonucleic acid and phosphorus of an n-paraffin-grown yeast, when given to colostomised laying hens. J. Sci. Food Agric. 24: 27-34.

- , McNAB, J. M. \& ANDERSON, G. B. 1976. Use of an n-paraffin-grown yeast in diets for replacement pullets and laying hens. J. Sci. Fd. Agric. 27: 471-476.

TAUSSKY, H. H. \& SHORRE, E. 1953. A microcalorimetric method for the determination of inorganic phosphorus. J. Biol. Chem. 202: 675-685. 
VOGT, H., HARNISCH, S. \& TORGES, H.-G. 1975. Bakterienprotein (Methanol-FermentationsProtein) im Geflügelfutter. Arch. Geflügelk. 39: 146-151.

- , KRIEG, R. \& HARNISCH, S. 1978. Alkanhefe Viton im Geflügelfutter. Arch. Geflügelk. 42: 201-207.

van WEERDEN, J.-E. \& SCHUTTE, J. BN. 1977. SCP-Eurolysine in rations for broilers. ILOB-report 427,7 p. Wageningen.

WHALDROUP, P. W. \& HAZEN, K. R. 1975. Yeast grown on hydrocarbon fractions as a protein source in the diet of laying hens. Poult. Sci. 54: 635-637.

WHITTEMOORE, C. T., GILCHRIST SHIRLAW, D. W., McDONALD, D. B. \& TAYLOR, A. G. 1978. Performance of broilers and layers given diets containing dried microbial cells (Pruteen). Br. Poult. Sci. 19:283.

Ms received July 19,1982

\section{Eurolysine bakteeriproteiini ja pekiloproteiini munivien kanojen valkuaisen lähteenä}

\section{Matti Näsi}

Helsingin yliopisto, kotieläintieteen laitos 00710 Helsinki 71

Tutkimuksessa selvitettiin kahden mikrobivalkuaistuotteen, eurolysine bakteeriproteiinin ja pekiloproteiinin käyttökelpoisuutta munivien kanojen valkuaisrehuna. Eurolysinen valkuaispitoisuus oli $68.5 \%$ ja lysiinipitoisuus $8.3 \mathrm{~g} / 16 \mathrm{~g} \mathrm{~N}$. Pekilon valkuaispitoisuus oli $43.3 \%$ ja lysiinipitoisuus $5.5 \mathrm{~g} / 16 \mathrm{~g} \mathrm{~N}$. Molemmissa mikrobiproteiinituotteissa metioniinipitoisuus oli alhainen. Kokeessa oli 504 kanaa jaettuna seitsemään ryhmään ja koe kesti 24 viikkoa. Eri rehuseoksissa oli eurolysineä $0-4.0-7.9$ ja $11.9 \%$ ja pekiloa $0-6.3-12.7-18.0 \%$ eli 33, 66 tai $100 \%$ valkuaislisästä, joka oli puoliksi soijaa ja kalajauhoa. Mikrobivalkuaista sisältävillä rehuseoksilla munintatulokset jäivät alemmiksi kuin soijalla ja kalajauholla. Samoin rehunkulutus lisääntyi mikrobiproteiinia sisältävillä ruokinnoilla. Erot rehuhyötysuhteessa eivät olleet merkitseviä. Kuolleisuus lisääntyi ryhmissä, jotka saivat mikrobiproteiinia, mutta kannibalismi oli pääasiallisin syy kuolemiin. 